\title{
Short-term thermal stratification and partial overturning events in a warm polymictic reservoir: effects on distribution of phytoplankton community
}

\author{
Santos, RM. ${ }^{a *}$, Saggio, AA. ${ }^{b}$, Silva, TLR. ${ }^{c}$, Negreiros, NF. ${ }^{a}$ and Rocha, $O .^{b}$ \\ aprograma de Pós-graduação em Ecologia e Recursos Naturais, Universidade Federal de São Carlos - UFSCar, \\ Rodovia Washington Luiz, Km 235, CP 676, Bairro Monjolinho, CEP 13565-905, São Carlos, SP, Brazil \\ bDepartamento de Ecologia e Biologia Evolutiva, Universidade Federal de São Carlos - UFSCar, \\ Rodovia Washington Luiz, Km 235, CP 676, Bairro Monjolinho, CEP 13565-905, São Carlos, SP, Brazil \\ 'Programa de Pós-graduação em Ciências da Engenharia Ambiental, Centro de Recursos Hídricos e Ecologia Aplicada, \\ Escola de Engenharia de São Carlos, Universidade de São Paulo - USP, Avenida Trabalhador Sancarlense, \\ 400, CEP 13564-040, São Carlos, SP, Brazil \\ *e-mail: renata_cordis@yahoo.com.br
}

Received: April 23, 2013 - Accepted: November 7, 2013 - Distributed: March 31, 2015

(With 6 figures)

\begin{abstract}
In lentic freshwater ecosystems, patterns of thermal stratification play a considerable part in determining the population dynamics of phytoplankton. In this study we investigated how these thermal patterns and the associated hydrodynamic processes affect the vertical distribution of phytoplankton during two consecutive diel cycles in a warm polymictic urban reservoir in the metropolitan region of São Paulo, Brazil. Water samples were taken and physical, chemical and biological data collected at half-meter intervals of depth along a water column at a fixed site, every 3 hours throughout the 48-hour period. Two events of stratification, followed by deepening of the thermocline occurred during the study period and led to changes in the vertical distribution of phytoplankton populations. Aphanocapsa delicatissima Nägeli was the single dominant species throughout the 48-hour period. In the second diel cycle, the density gradient induced by temperature differences avoided the sedimentation of Mougeotia sp. C. Agardh to the deepest layers. On the other hand, Pseudanabaena galeata Böcher remained in the 4.0-5.5 m deep layer. The thermal structure of the water was directly affected by two meteorological factors: air temperature and wind speed. Changes in the cell density and vertical distribution of the phytoplankton were controlled by the thermal and hydrodynamic events.
\end{abstract}

Keywords: phytoplankton, thermohydrodynamics, thermal stratification, diel variation, Guarapiranga reservoir.

\section{Estratificação térmica de curto prazo e eventos de desestratificação parcial em um reservatório polimítico quente: efeitos sobre a distribuição da comunidade fitoplanctônica}

\section{Resumo}

Em ecossistemas de água doce, os padrões de estratificação térmica têm uma influência considerável sobre a dinâmica populacional do fitoplâncton. Neste estudo nós investigamos como os padrões de estratificação térmica e os processos hidrodinâmicos afetaram a distribuição vertical do fitoplâncton durante dois ciclos nictemerais consecutivos em um reservatório urbano na cidade de São Paulo. As amostragens e medidas das variáveis físicas e químicas foram realizadas a cada três horas durante um período de 48 horas, ao longo de um perfil vertical. Ocorreram dois eventos de estratificação e subsequente abaixamento da termoclina acarretando alterações na distribuição vertical do fitoplâncton. Aphanocapsa delicatissima Nägeli foi a principal espécie dominante durante todo o período avaliado. No segundo ciclo nictemeral o gradiente de densidade criado pelas diferenças de temperatura impediu o afundamento de Mougeotia sp. C. Agardh para as camadas mais profundas. Por outro lado Pseudoanabaena galeata Böcher se manteve nas camadas de 4.0 e $5.5 \mathrm{~m}$. A estrutura térmica da água foi diretamente afetada pelos fatores meteorológicos temperatura do ar e velocidade do vento. As mudanças na densidade e na distribuição vertical do fitoplâncton foram controladas pelos eventos térmicos e hidrodinâmicos.

Palavras-chave: fitoplâncton, termohidrodinâmica, estratificação térmica, variação nictemeral, reservatório de Guarapiranga. 


\section{Introduction}

Thermal stratification is an important natural phenomenon in aquatic systems, which interferes significantly with their physical and chemical structure, creating complex gradients or simply leading to increased heterogeneity of the water column. The stratification pattern and the temperature of the upper mixed layer depend greatly on the latitude; thus the changes in stability are much more variable in the short term in tropical than in temperate lakes, particularly if winds are strong enough to cause vigorous motion in the upper water layer (Lewis, 1987; Cantin et al., 2011).

Recent research has drawn attention to the fact that the ecological study of plankton communities in lakes and reservoirs requires more than the traditional limnological approach, based on the chemical analysis of the water body and the biology of the component microorganisms. Physical data are also needed, particularly with regard to the thermal hydrodynamics of the water body (MacIntyre et al., 2002), since the stratification pattern is a distinctive feature and a key to understand the dynamics of plankton communities in tropical lakes (Sarmento, 2012). In other words, those physical processes are the primary causes of first-order effects that then propagate through numerous and more complex effects of an ecological nature (Lewis, 1987).

The thermal hydrodynamics of warm polymictic reservoirs is normally governed by density gradients. According to Reynolds (1984), changes in water density resulting from a rise of $1^{\circ} \mathrm{C}$ from $24^{\circ} \mathrm{C}$ to $25^{\circ} \mathrm{C}$ is about 3 times as large as that observed between $4^{\circ} \mathrm{C}$ and $5^{\circ} \mathrm{C}$, increasing the likelihood of distinct, stable layers being formed in warm regions. However, the heat distribution and thus the density gradients in tropical lakes are constantly changing, these water-bodies being more susceptible to numerous partial mixing events, usually tending to become stratified in the daytime and mixed at night (Lewis, 1987; Sarmento, 2012).

In temperate climates, the thermal stratification patterns in lakes are mainly associated with seasons (Hutchinson, 1957; Imberger and Patterson, 1989), showing a welldefined sequence of events. By contrast, in tropical regions, where seasons are less marked, lake stratification tends to be associated with a sequence of short-term climatic events (such as intense solar radiation, torrential rain, cold fronts or strong winds), which promote multiple cycles of stratification and partial overturning over short time intervals (Talling, 1966; Barbosa and Padisák, 2002; Becker et al., 2009).

Among the various freshwater communities, phytoplankton is particularly affected by the turbulent mixing processes in the water, and stratification and overturning events have a great importance in several features of algal ecology (Reynolds, 1984; Lopes et al., 2005). The composition, vertical distribution and primary productivity of algal populations are directly affected by the interaction of various factors that modulate the thermal and chemical structure of the water column, notably the heat flux, wind velocity, density, viscosity and nutrient availability (Cantin et al., 2011).

The conditions in which phytoplankton live are evidently heterogeneous, the most variable environmental factors being temperature, irradiation, water flow and nutrients availability. According to Reynolds (1984), an adequate understanding of phytoplankton ecology depends on the knowledge of habitat heterogeneity, of the phenomena that produce that heterogeneity, and patterns of distribution of the organisms in space and time.

The objectives of this study were to determine how the physical structure of the water column influences the vertical distribution of phytoplankton in a warm polymictic tropical reservoir used for the public water supply. The main questions posed in this study were: i) How do metereological factors alter the thermal regime in the Guarapiranga reservoir in the short term? ii) How does the phytoplankton community respond to thermal and hydrodynamic events, in terms of changes in population densities and vertical distribution?

\section{Material and Methods}

\subsection{Study area}

The Guarapiranga $\left(23^{\circ} 46^{\prime} \mathrm{S}\right.$; $\left.46^{\circ} 43^{\prime} \mathrm{W}\right)$ is a large subtropical polymictic reservoir (Gemelgo et al., 2009) located in the Upper Tietê River basin (Figure 1). This reservoir has $33 \mathrm{~km}^{2}$ surface area, $5.7 \mathrm{~m}$ mean depth and $185 \mathrm{~d}$ water retention time (Beyruth, 2000). It forms part of the water supply system for the Metropolitan Region of São Paulo, contributing around $20 \%$ of the water consumed, and is the second longest freshwater body in this region. Since the 1970s, the local population density has risen and conservation areas around the reservoir have been occupied. This process, coupled with the absence of an effective municipal sewage system in the catchment area of the reservoir, has led to an accelerated eutrophication and a fall in the water quality (Beyruth, 2000).

\subsection{Meteorological variables}

Air temperature and wind speed and direction were recorded throughout the study period, at intervals of $10 \mathrm{~s}$, by means of a floating weather station located near the dam. Rainfall data were collected every 10 minutes from a public weather station located a distance of $5 \mathrm{~km}$ from the sampling point.

\subsection{Physical and chemical water variables}

Samples of water were taken for chemical analysis from depths of $0.0,2.0,4.0$ and $5.5 \mathrm{~m}$, near the point of entry of the Embu-Mirim tributary stream into the Guarapiranga reservoir (2342'53's and 46 $44^{\circ} 32^{\prime}$ 'W), every 3 hours for a $48 \mathrm{~h}$ period, from September $12^{\text {th }}$ to $14^{\text {th }}, 2010$ (dry season). The site was chosen for its frequent cyanobacterial blooms. The samples were frozen and analyzed for total nitrogen and phosphorus contents in the laboratory by ion chromatography according to the methods described by Colina and Gardiner (1999). Temperature, dissolved oxygen concentration, $\mathrm{pH}$ and 


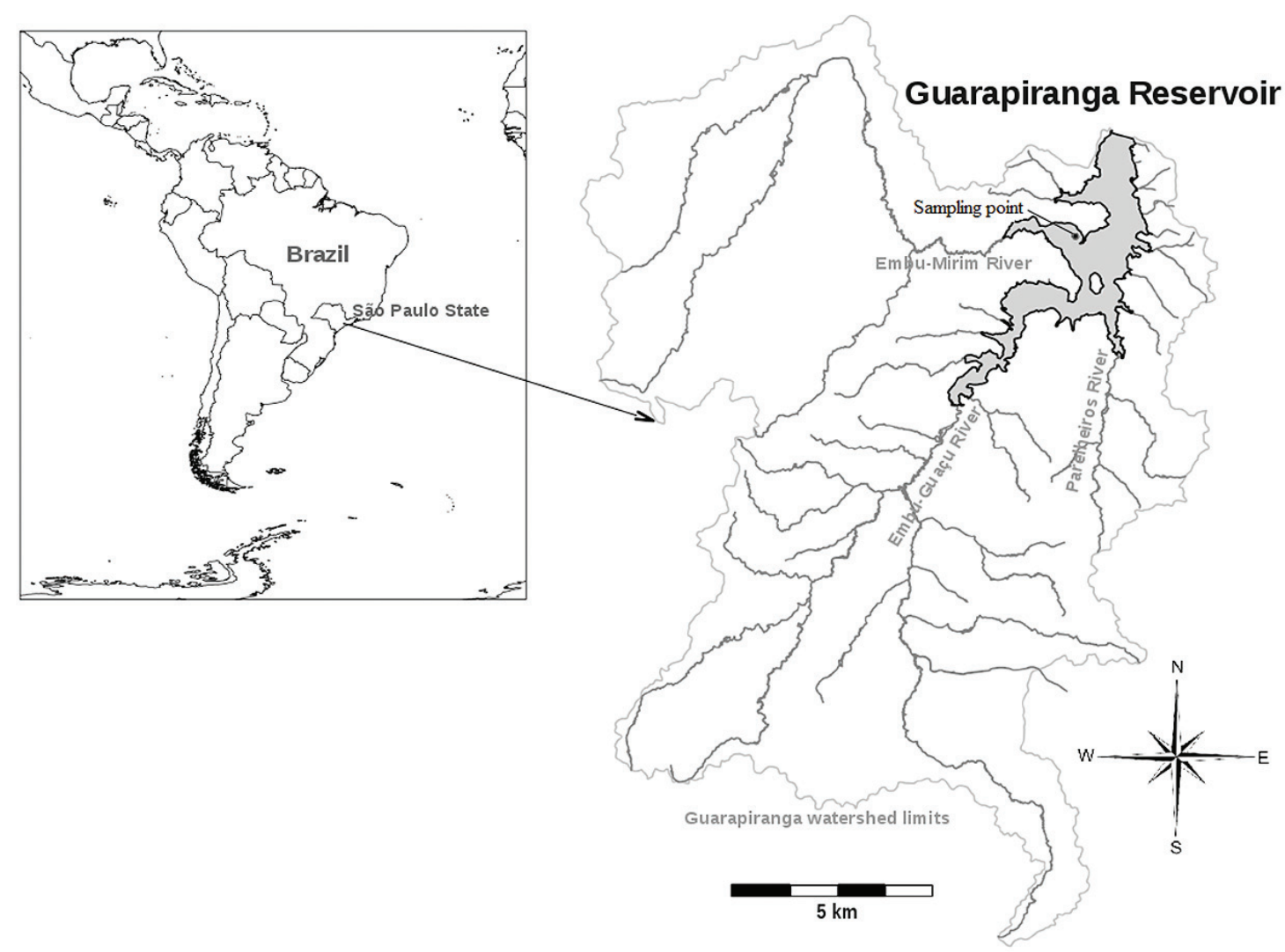

Figure 1. Map of Brazil showing location of Guarapiranga Reservoir, main tributaries and sampling site.

electrical conductivity of the water were measured in situ, at intervals of $0.5 \mathrm{~m}$ from the surface down to a depth of $5.5 \mathrm{~m}$, with an U-10 Horiba portable multiprobe. The transparency of the water and euphotic zone depth (defined as $1 \%$ of surface irradiance) were determined as described by Margalef (1983), from Secchi disk readings.

\subsection{Biological variables}

A total of 64 phytoplankton samples were collected in $5 \mathrm{~L}$ Van Dorn bottles, from depths of 0.0, 2.0, 4.0 and $5.5 \mathrm{~m}$, and fixed with neutral lugol solution. Individual algae were counted by examination in a Zeiss Axiovert inverted microscope, after prior sedimentation of a $10 \mathrm{~mL}$ sub-sample in an Utermöhl chamber. The time allowed for sedimentation was three hours per cm depth of the sample in the chamber (Utermöhl, 1958). Counting was carried out in horizontal and vertical transects of the field view and the density was calculated by the formula proposed by Ros (1979) and expressed in number of cells per milliliter (cells $\mathrm{mL}^{-1}$ ).

Chlorophyll $a$ concentrations were determined by spectrophotometric methods, as described in Nush (1980), by hot extraction in $90 \%$ ethanol.

\subsection{Trophic State Index (TSI)}

The trophic state index (TSI) was calculated according to Carlson (1977), modified by Toledo et al. (1983), considering the total phosphorous concentration values. The following criteria were used to classify the trophic state: oligotrophic - TSI $\leq 44$; mesotrophic- $44<\mathrm{TSI} \leq 54$; and eutrophic $-\mathrm{TSI}>54$.

\subsection{Statistical analysis}

Analysis of variance (ANOVA post-hoc $t$-test significance accepted when $\mathrm{p} \leq 0.05)$ was used to test for significant differences in phytoplankton density, between distinct depths, employing the free program PAST 1.79 (Hammer et al., 2001). Principal components analysis (PCA), available in the computer program CANOCO 3.12 (Ter Braak and Šmilauer, 2002) was carried out to summarize the main patterns of variation within the physical and chemical variables in the water and to order the samples with respect to their chemical and limnological characteristics. The data for the dominant phytoplankton species were transformed by the function $\log (x+1)$ to normalize them and then subjected to redundancy analysis (RDA), again employing CANOCO 3.12. The Monte Carlo test, with 4999 random permutations was used to test for significant associations between independent significantly correlated abiotic (water temperature and depth) and biological (chlorophyll $a$ concentration and phytoplankton density) variables. 


\section{Results}

\subsection{Diel variations of meteorological and water column variables}

The fluctuations in wind speed, wind direction and air temperature recorded at the sampling times, are presented in Table 1. At the beginning of the study, at 10:00 am on September $12^{\text {th }}, 2010$, the air temperature was $20.0^{\circ} \mathrm{C}$ and a wind of $1.5 \mathrm{~m} \mathrm{~s}^{-1}$ was blowing from the South. From 7:00 pm until 7:00 am on September $13^{\text {th }}$, meteorological conditions changed. The wind speed increased to $4.0 \mathrm{~m} \mathrm{~s}^{-1}$ and changed direction, now blowing from the North (Table 1). Air temperature also varied widely, the amplitude of variation reaching $14^{\circ} \mathrm{C}$. Higher temperatures of around $30.0{ }^{\circ} \mathrm{C}$ occurred on the afternoon of September $13^{\text {th }}$. Simultaneously, the wind speed varied from $0.0 \mathrm{~m} \mathrm{~s}^{-1}$ to a strong breeze ( 4.0 to $5.0 \mathrm{~m} \mathrm{~s}^{-1}$ ). No rain fell in this period or in the previous 48 hours.
In the second diel cycle, beginning at 10:00 am on September $13^{\text {th }}$, the air temperature rose gradually from $17^{\circ} \mathrm{C}$ to the maximum recorded value of $29.8^{\circ} \mathrm{C}$ at $4: 00$ $\mathrm{pm}$, then fell steadily until 10:00 pm and warmed up again throughout the night and early morning.

\subsection{Physical and chemical characteristics of water column}

Water physical and chemical conditions also varied with depth, as shown in Table 2. The $\mathrm{pH}$ ranged from slightly basic at the surface to slightly acidic near the bottom $(7.15 \pm 0.65)$. Total nitrogen and total phosphorus concentrations were high at all depths $\left(1,932.84 \pm 264.42 \mu \mathrm{g} \mathrm{L}^{-1}\right.$ and $40.8 \pm 11.19 \mu \mathrm{g} \mathrm{L}^{-1}$ respectively) and chlorophyll $a$ concentrations were also high $\left(27.55 \pm 8.5 \mu \mathrm{g} \mathrm{L}^{-1}\right)$ with lowest values at $5.5 \mathrm{~m}$.

The euphotic zone reached a maximum depth of $3.18 \mathrm{~m}$ on September $13^{\text {th }}$ at $4: 00 \mathrm{pm}$, coinciding with

Table 1. Wind speed and air temperature recorded by a floating weather station during the study period, from 10 am on September 12 to 10 am on September 14, 2010.

\begin{tabular}{|c|c|c|c|c|}
\hline Day & Hour & Wind speed $\left(\mathrm{m} \mathrm{s}^{-1}\right)$ & Wind direction $\left({ }^{\circ}\right)$ & Air temperature $\left({ }^{\circ} \mathrm{C}\right)$ \\
\hline \multirow[t]{5}{*}{ Sept 12} & 10:00 am & 1.50 & $180 \uparrow$ & 20.25 \\
\hline & $1: 00 \mathrm{pm}$ & 1.50 & $180 \uparrow$ & 26.45 \\
\hline & 4:00 pm & 3.67 & $167 \uparrow$ & 23.20 \\
\hline & $7: 00 \mathrm{pm}$ & 2.65 & $180 \uparrow$ & 20.10 \\
\hline & $10: 00 \mathrm{pm}$ & 0.52 & $154 \uparrow$ & 18.40 \\
\hline \multirow[t]{8}{*}{ Sept 13} & 1:00 am & 0 & & 17.20 \\
\hline & 4:00 am & 0.23 & & 16.60 \\
\hline & 7:00 am & 0 & & 17.00 \\
\hline & 10:00 am & 3.93 & $30 \ltimes$ & 24.14 \\
\hline & $1: 00 \mathrm{pm}$ & 3.46 & $54 k$ & 28.16 \\
\hline & 4:00 pm & 2.36 & $26 \downarrow$ & 29.85 \\
\hline & 7:00 pm & 1.24 & $232 \pi$ & 23.64 \\
\hline & $10: 00 \mathrm{pm}$ & 0 & & 19.09 \\
\hline \multirow[t]{4}{*}{ Sept 14} & 1:00 am & 0 & & 19.55 \\
\hline & 4:00 am & 4.32 & $332 \downarrow$ & 22.40 \\
\hline & 7:00 am & 2.14 & $360 \downarrow$ & 21.50 \\
\hline & 10:00 am & 4.14 & $5 \downarrow$ & 25.12 \\
\hline
\end{tabular}

Wind direction defined clockwise, $0^{\circ}$ being wind from North.

Table 2. Mean values of physical and chemical variables and calculated trophic state index (TSI) for Guarapiranga Reservoir, between $10 \mathrm{am}$, September 12 and $10 \mathrm{am}$, September 14, 2010.

\begin{tabular}{lcccc}
\hline & $\mathbf{0 . 0} \mathbf{~ m}$ & $\mathbf{2 . 0} \mathbf{~ m}$ & $\mathbf{4 . 0} \mathbf{~ m}$ & $\mathbf{5 . 5} \mathbf{~ m}$ \\
\hline Secchi $(\mathrm{m})$ & $1.0 \pm 0,1$ & -- & -- & -- \\
Euphotic Zone $(\mathrm{m})$ & $2.8 \pm 0.2$ & -- & -- & -- \\
Water Temperature $\left({ }^{\circ} \mathrm{C}\right)$ & $20.4 \pm 0.6$ & $19.7 \pm 0.5$ & $18.7 \pm 0.5$ & $18.2 \pm 0.2$ \\
$\mathrm{pH}$ & $7.8 \pm 0.6$ & $7.4 \pm 0.4$ & $6.9 \pm 0.3$ & $6.3 \pm 0.3$ \\
Conductivity $\left(\mu \mathrm{S} \mathrm{cm}^{-1}\right)$ & $102.9 \pm 5.2$ & $104.2 \pm 5.0$ & $103.4 \pm 3.1$ & $101.4 \pm 6.1$ \\
Dissolved oxygen $\left(\mathrm{mg} \mathrm{L}^{-1}\right)$ & $9.6 \pm 1.2$ & $7.6 \pm 1.5$ & $3.3 \pm 2.5$ & $1.1 \pm 1.1$ \\
Total nitrogen $\left(\mu \mathrm{g} \mathrm{L}^{-1}\right)$ & $1912.4 \pm 198.8$ & $2076.3 \pm 163.9$ & $1883.9 \pm 335.7$ & $1854.9 \pm 287.1$ \\
Total phosphorus $\left(\mu \mathrm{g} \mathrm{L}^{-1}\right)$ & $42.5 \pm 8.7$ & $44.3 \pm 10.2$ & $38.3 \pm 13.5$ & $38.1 \pm 11.4$ \\
Chlorophyll $a\left(\mu \mathrm{g} \mathrm{L}^{-1}\right)$ & $32.4 \pm 5.1$ & $34.2 \pm 6.2$ & $22.8 \pm 6.3$ & $20.8 \pm 6.5$ \\
TSI & $>62$ & & &
\end{tabular}


the higher surface dissolved oxygen (DO) concentration and warmer water (Figure 2). In the deepest layer $(5.5 \mathrm{~m}$ below surface), low DO concentrations were recorded, with complete anoxia beyond $5.5 \mathrm{~m}$ (Table 2), while at the surface the DO concentration was generally high (e.g. $12.5 \mathrm{mg} \mathrm{L}^{-1}$ at 4:00 $\mathrm{pm}$ on September $13^{\text {th }}$ ).

The trophic state index (TSI, Table 2) indicated that Guarapiranga Reservoir could be classed as eutrophic during the study period.

\subsection{Diel changes in the thermal, chemical and biological structure of the water column}

Changes in the thermal, chemical and biological profiles of the water column were analyzed in detail at a fixed site over two consecutive diel cycles starting at 10 am on September $12^{\text {th }}, 2010$.

The water column was initially characterized by moderate stratification, with a temperature gradient of less than $1{ }^{\circ} \mathrm{C}$ in the $1.0 \mathrm{~m}$ thick epilimnion and a moderately
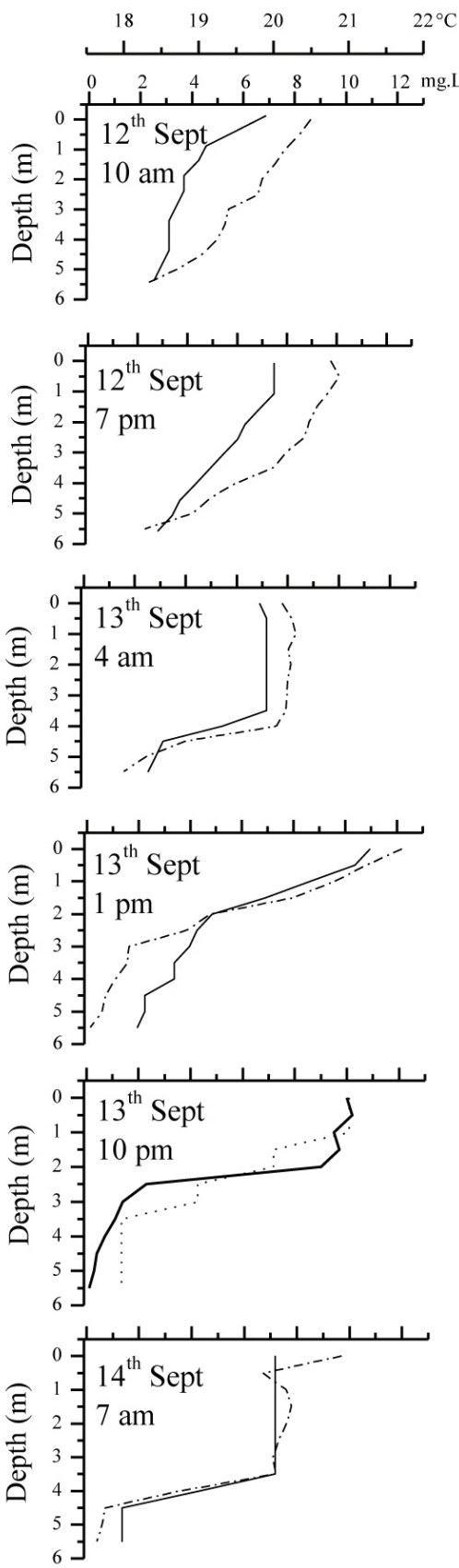
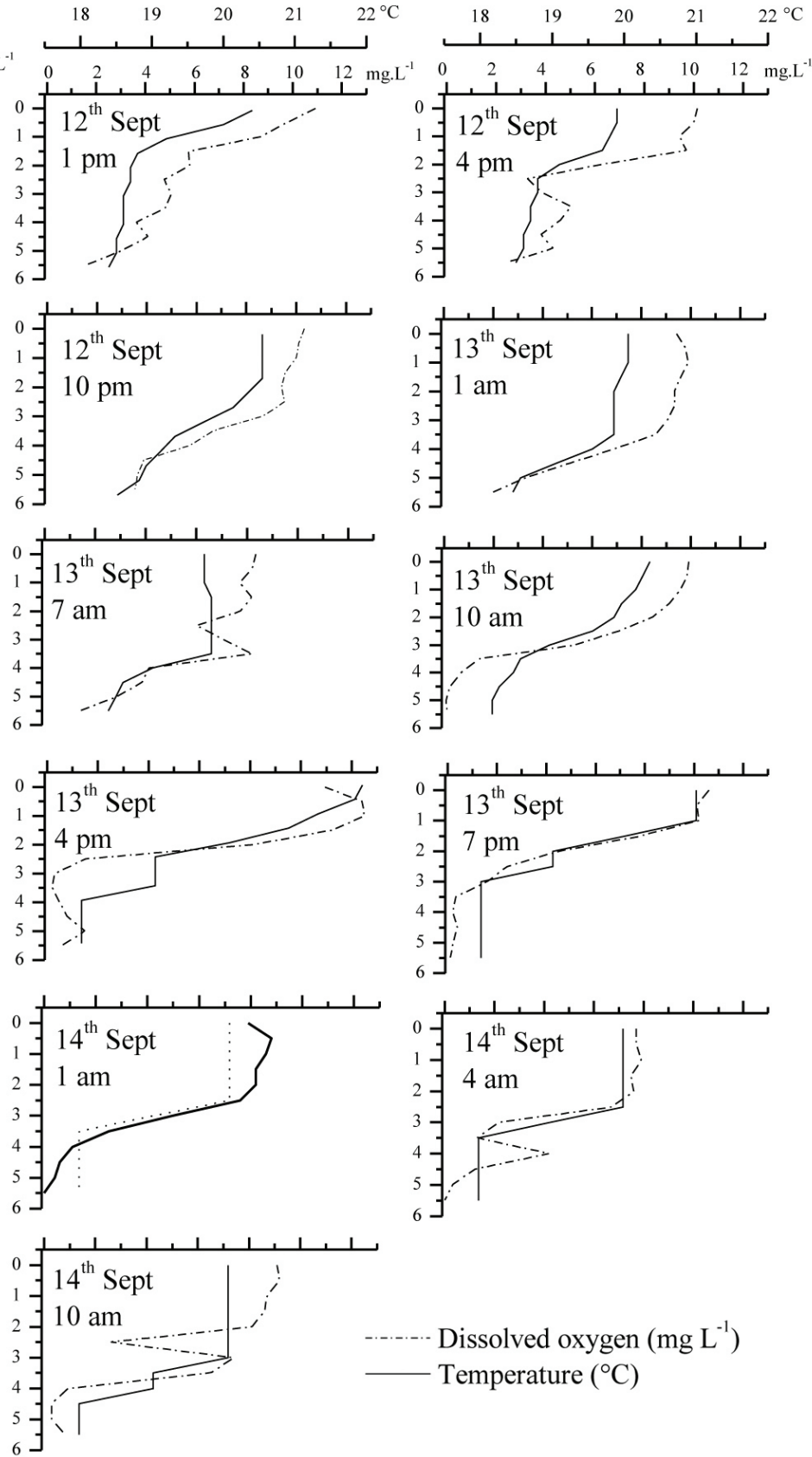

Dissolved oxygen $\left(\mathrm{mg} \mathrm{L}^{-1}\right)$ Temperature $\left({ }^{\circ} \mathrm{C}\right)$

Figure 2. Profiles of water temperature $\left({ }^{\circ} \mathrm{C}\right)$ and dissolved oxygen concentration $\left(\mathrm{mg} \mathrm{L}^{-1}\right)$ against depth at a fixed site in Guarapiranga Reservoir (SP, Brazil), at intervals of $3 \mathrm{~h}$ from $10 \mathrm{am}$ on the $12^{\text {th }}$ to $10 \mathrm{am}$ on the $14^{\text {th }}$ of September, 2010. 
well defined metalimnion. During the day it progressively formed a stepped thermal structure, returning after 4:00 pm to moderate stratification.

During the night time, with more or less stable temperatures and little wind, the stepped structure was eroded, while the thermocline deepened to $3.5 \mathrm{~m}$ increasing the thickness of the mixing layer. A homogeneous and deep epilimnion (down to $3.5 \mathrm{~m}$ ) appeared in the profiles from 1:00 am till 7:00 am on September 13 $3^{\text {th }}$.

A third period between 10:00 am and 10:00 pm on September $13^{\text {th }}$ exhibited the same sequence of heat penetrating the upper layers and generating the stepped pattern in the thick metalimnion. From 1:00 pm on September $13^{\text {th }}$ the air temperature rose from $17^{\circ} \mathrm{C}$ to $29.8^{\circ} \mathrm{C}$ (at 4:00 pm), leading to the strongest thermal stratification recorded in the period of study. At 4:00 pm, the water temperature in the epilimnion was also at its highest $\left(21.8^{\circ} \mathrm{C}\right)$ and there was the steepest gradient $\left(3.7^{\circ} \mathrm{C}\right)$ in the metalimnion (Figure 2). Meanwhile, the depth of the metalimnion at $4.0-5.0 \mathrm{~m}$ in the early hours of September $13^{\text {th }}$, to reach $2.0 \mathrm{~m}$ at 1:00 pm, where it stays until 7:00 pm.

After the wind ceased, around 10:00 pm a new thermohydrodynamic event started, characterized by thermocline deepening and this extended until the end of the study, at 10:00 $\mathrm{pm}$ on September $14^{\text {th }}$.

\subsection{Phytoplankton composition and dominant species vertical distribution}

In the period of this study, 68 taxa of algae and cyanobacteria were identified in the phytoplankton community in Guarapiranga, most belonging to Chlorophyceae (41\%), Cyanobacteria (25\%) and Bacillariophyceae (12\%).

In terms of numerical abundance, the dominant species was the cyanobacterium Aphanocapsa delicatissima Nägeli. Also abundant were the chlorophyceans Scenedesmus ecornis (Ehrenberg) Chodat, Eudorina elegans Ehrenberg, Monoraphidium contortum (Thuret) Komárková-Legnerová and Mougeotia sp. C. Agardh. Species contributing more than $5 \%$ of the total phytoplankton density were included in the analysis of changes in the vertical distribution during the 48-hour period. Together, these species represented more than $78 \%$ of the total abundance of phytoplankton.

The highest densities occurred at depths 0.0 and $2.0 \mathrm{~m}$ and the lowest at $5.5 \mathrm{~m}$ (Figure 3). A. delicatissima was numerically dominant throughout the study period at almost all sampling depths and time intervals. An exception was the sample taken at $4.0 \mathrm{~m}$ depth, on September $13^{\text {th }}$ at 7:00 am, when Scenedesmus ecornis was the dominant species. This chlorophycean was the most abundant species among the Chlorophyta in the majority of samples analyzed (Figure 3).

Pseudanabaena galeata was another cyanobacterium occurring in all samples, except on September $13^{\text {th }}$ at 7:00 am. This species occurred in noticeable densities only at $5.5 \mathrm{~m}$, although a few cells were also found in the sample from $4.0 \mathrm{~m}$.

Synechococcus sp. occurred at low densities throughout the study period. With the rising temperatures and strong winds that characterized the daytime of the second diel period (7:00 am to 7:00 pm September 13 ${ }^{\text {th }}$ ), the Synechococcus $\mathrm{sp}$. abundance increased approximately eight times.

The distribution of Cryptomonas sp. was heterogeneous in the water column, but the highest density values were always recorded near the surface $(0.0 \mathrm{~m})$. A more homogeneous distribution was only observed at 1:00 am on September $13^{\text {th }}, 2010$.

Similarly to Cryptomonas sp., Eudorina elegans remained in the upper layers $(0.0$ and $2.0 \mathrm{~m})$. In the period between 1:00 am and 7:00 am, on both days, E. elegans densities increased around four times.

As for most species of algae occurring in Guarapiranga Reservoir, Mougeotia sp. was abundant at 0.0 and $2.0 \mathrm{~m}$ depths. Only at 7:00 and 10:00 pm on September $12^{\text {th }}$ and 4:00 am on September $13^{\text {th }}$ were higher densities of this species recorded in the deepest layer $(5.5 \mathrm{~m})$.

Following the same pattern Monoraphidiun contortum was also more abundant in the upper layers $(0.0$ and $2.0 \mathrm{~m})$, except at 4:00 am on September 13 ${ }^{\text {th }}$, when like Mougeotia sp. it was more numerous at greater depth (Figure 3A)

3.5. Short-term changes in vertical distribution of whole phytoplankton community

Phytoplankton density and chlorophyll $a$ concentration differed among water layers (depths) and sampling times following changes in the thermal structure. The vertical distribution of the whole phytoplankton community and temperature profiles are presented together, for each time interval sampled, in Figure 4.

In the first period, from 10:00 am to $10: 00 \mathrm{pm}$ on September $12^{\text {th }}$, algal populations were quite evenly distributed in the water column. Mean densities were 5,917 $( \pm 1,184)$ cells $\mathrm{mL}^{-1} ; 6,071( \pm 1,674)$ cells $\mathrm{mL}^{-1} ; 4,507$ $( \pm 1,019)$ and 5,965 cells $\mathrm{mL}^{-1}( \pm 1,399)$ at $0.0 ; 2.0,4.0$ and $5.5 \mathrm{~m}$ respectively. There were no significant differences in phytoplankton densities between the sampled depths $(\mathrm{F}=1.526 ; d f=3 ; p=0.2461)$.

In the second period, characterized by overturning in the epilimnion and deepening of the thermocline, from 1:00 am until 7:00 am on September $13^{\text {th }}$ phytoplankton distribution was heterogeneous with high densities in the two upper layers, with $10,419( \pm 1,541)$ cells $\mathrm{mL}^{-1}$ and $8,442( \pm 1,431)$ cells $\mathrm{mL}^{-1}$ at 0.0 and $2.0 \mathrm{~m}$ respectively, and low in the deeper layers, with $5,025( \pm 1,429)$ and $4,100( \pm 2,237)$ cells $\mathrm{mL}^{-1}$ at 4.0 e $5.5 \mathrm{~m}$ respectively. The ANOVA analysis showed significant differences between the total phytoplankton density at $0.0 \mathrm{~m}$ and those recorded at 2.0, 4.0 and $5.5 \mathrm{~m}(\mathrm{~F}=9,09, d f=3 ; p=0.005)$.

The following period (from 10:00 am to $10: 00 \mathrm{pm}$ on September $13^{\text {th }}$ ) was characterized by strong thermal stratification and a rise and fall in the thermocline. Phytoplankton was concentrated mainly at the surface where the density was $11,790( \pm 2,272)$ cells $\mathrm{mL}^{-1}$. Densities at other depths were $7,667( \pm 1,509)$ cells $\mathrm{mL}^{-1}$ at $2.0 \mathrm{~m}$; $5,574( \pm 800.6)$ at $4.0 \mathrm{~m}$; and 5,036 $( \pm 689.0)$ cells $\mathrm{mL}^{-1}$ at $5.5 \mathrm{~m}$. There were significant differences between depths $(\mathrm{F}=15.91, d f=3 ; p=0.0001)$, and the phytoplankton 

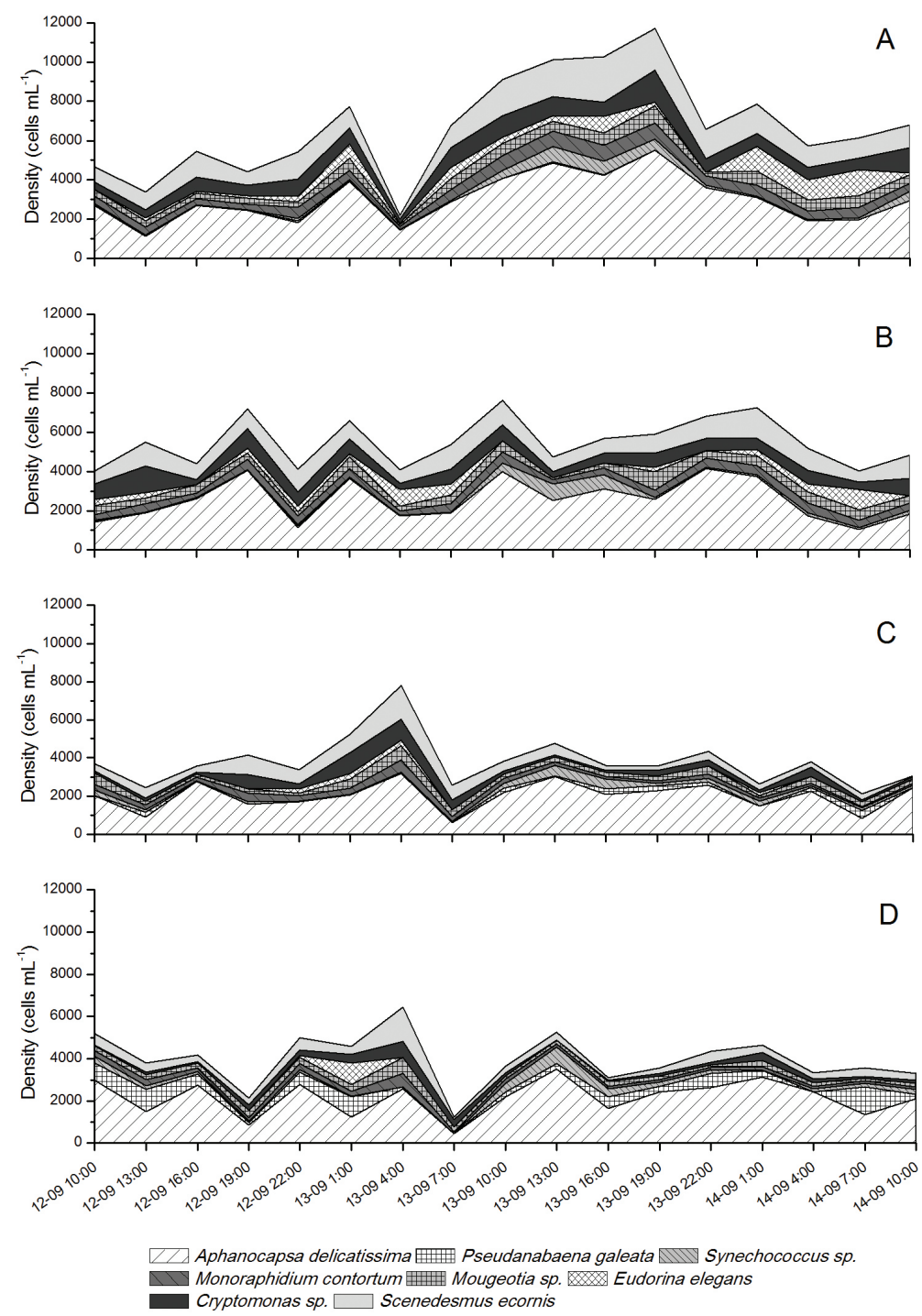

Figure 3. Cell density (cells $\mathrm{mL}^{-1}$ ) of the dominant phytoplankton species in Guarapiranga Reservoir (SP, Brazil), at various depths (A: $0.0 \mathrm{~m}, \mathrm{~B}: 2.0 \mathrm{~m}, \mathrm{C}: 4.0 \mathrm{~m}$ and D: $5.5 \mathrm{~m}$ ), each $3 \mathrm{~h}$ from 10:00 am on the $12^{\text {th }}$ to $10 \mathrm{am}$ on the $14^{\text {th }}$ of September, 2010.

density at $0.0 \mathrm{~m}$ was statistically different from that at 2.0 , 4.0 and $5.5 \mathrm{~m}$ depths $(p<0.05)$.

The last period (from 1:00 am to 10:00 am on September $14^{\text {th }}$ ), was characterized by night cooling and a deep thermocline, resulting in the redistribution of phytoplankton in the extended epilimnion. The highest mean density was found at $0.0 \mathrm{~m}(8,396 \pm 332.3$ cells $\left.\mathrm{mL}^{-1}\right)$ and the lowest at $4.0 \mathrm{~m}\left(4,299 \pm 349.7\right.$ cells $\left.\mathrm{mL}^{-1}\right)$. Statistical tests indicated significant differences between depths $(\mathrm{F}=9.41, d f=3 ; p=0.001)$. Phytoplankton densities at $0.0 \mathrm{~m}$ were statistically different from those at 4.0 and $5.5 \mathrm{~m}(\mathrm{p}<0.05)$ and the densities at $2.0 \mathrm{~m}$ also differed significantly from that at $4.0 \mathrm{~m}(p=0.046)$.

\subsection{Ordination analysis}

PCA analysis was performed to study the relationships between abiotic variables, water column depth and time intervals (Figure 5). There were strong relationships, as evidenced by the high explicability attained by the first two axes, which together explained $84.6 \%$ of the total variance. The first axis showed negative correlations between all abiotic variables and depth. This axis separated the surface and $2.0 \mathrm{~m}$ samples on the left side and 4.0 and $5.5 \mathrm{~m}$ depth on the right side. As expected, water temperature, dissolved oxygen concentration and $\mathrm{pH}$ were always higher in the surface layers, whereas the total nitrogen, total phosphorus and electrical conductivity, although also predominantly related to the surface layers, were sometimes related to the layer at $4.0 \mathrm{~m}$.

The RDA performed to reveal associations between the population densities of the dominant phytoplankton species and selected abiotic variables is shown in Figure 6. Phytoplankton population densities were strongly associated with the variables water temperature $(\mathrm{p}<0.05)$, chlorophyll 

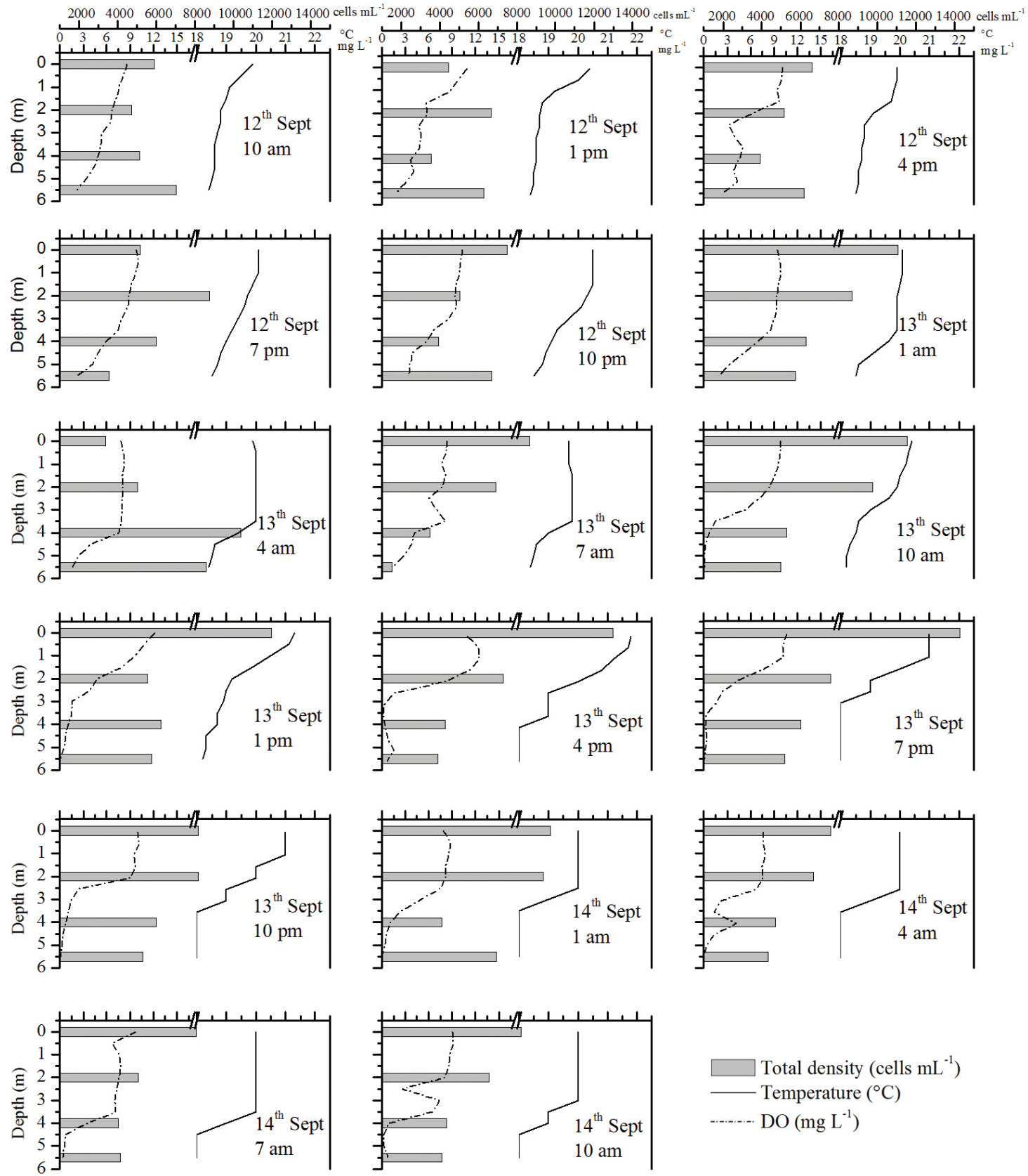

Figure 4. Profiles of water temperature $\left({ }^{\circ} \mathrm{C}\right)$, dissolved oxygen concentration $\left(\mathrm{mg} \mathrm{L}^{-1}\right)$ and total phytoplankton density (cells $\mathrm{mL}^{-1}$ ) measured at various depths in Guarapiranga Reservoir (SP, Brazil), at intervals of $3 \mathrm{~h}$ from 10 am on the $12^{\text {th }}$ to 10 am on the $14^{\text {th }}$ of September, 2010.

$a(\mathrm{p}<0.05)$ and depth and the first two axes explained 96.3 and $3.4 \%$ of the variance, respectively. Population densities of the chlorophyceans Scenedesmus ecornis, Monoraphidium contortum, Mougeotia sp. and Eudorina elegans, the cryptophycean Cryptomonas sp. and the cyanobacterium Aphanocapsa delicatissima were positively associated with the depths 0.0 and $2.0 \mathrm{~m}$ and also with high water temperature and chlorophyll $a$ concentration. On the other hand, population densities of the cyanobacterium
Synechococcus sp. and of Pseudanabaena galeata were negatively related to water temperature and chlorophyll $a$ concentration and positively related to water column depth, since they had high densities in the deep layers at 4.0 and $5.5 \mathrm{~m}$.

\section{Discussion}

During the period of study, the Guarapiranga Reservoir was subjected to two consecutive cycles of stratification 


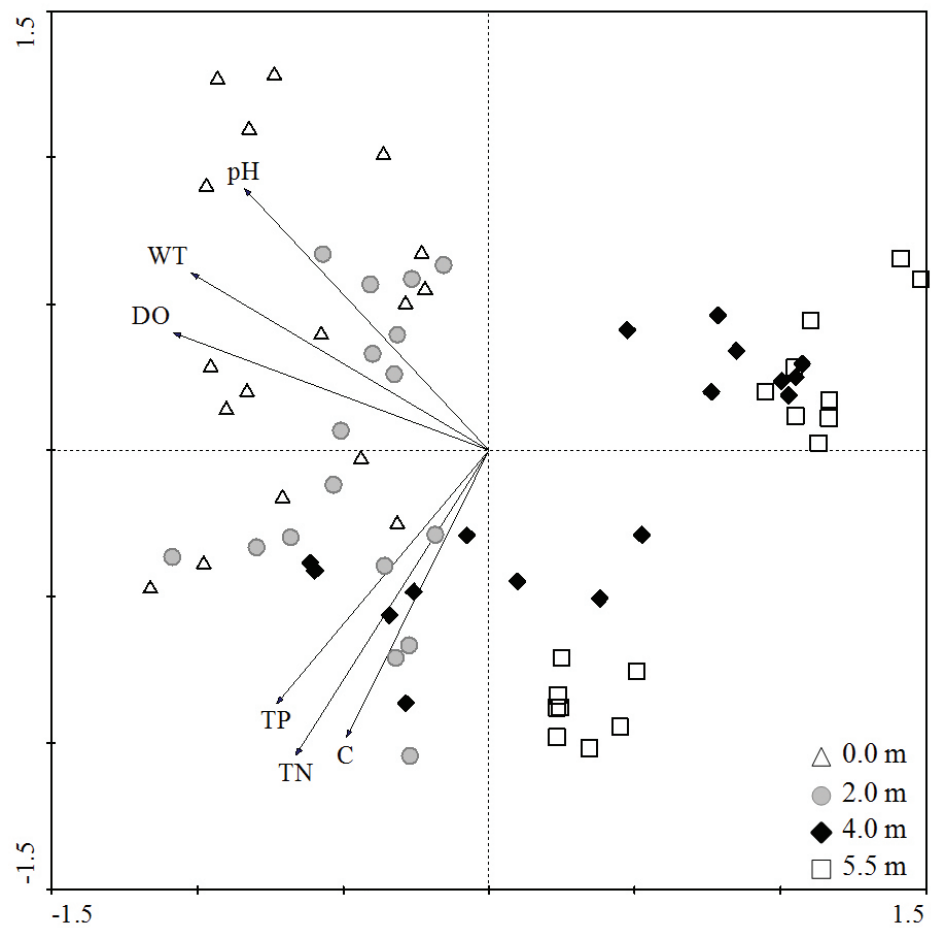

Figure 5. Principal components analysis (PCA) ordination diagram relating the physical and chemical variables with water column depths: $\mathrm{WT}=$ water temperature; $\mathrm{DO}=$ dissolved oxygen concentration; $\mathrm{C}=$ water electrical conductivity; $\mathrm{TP}=$ total phosphorus; $\mathrm{TN}=$ total nitrogen and $\mathrm{pH}$.

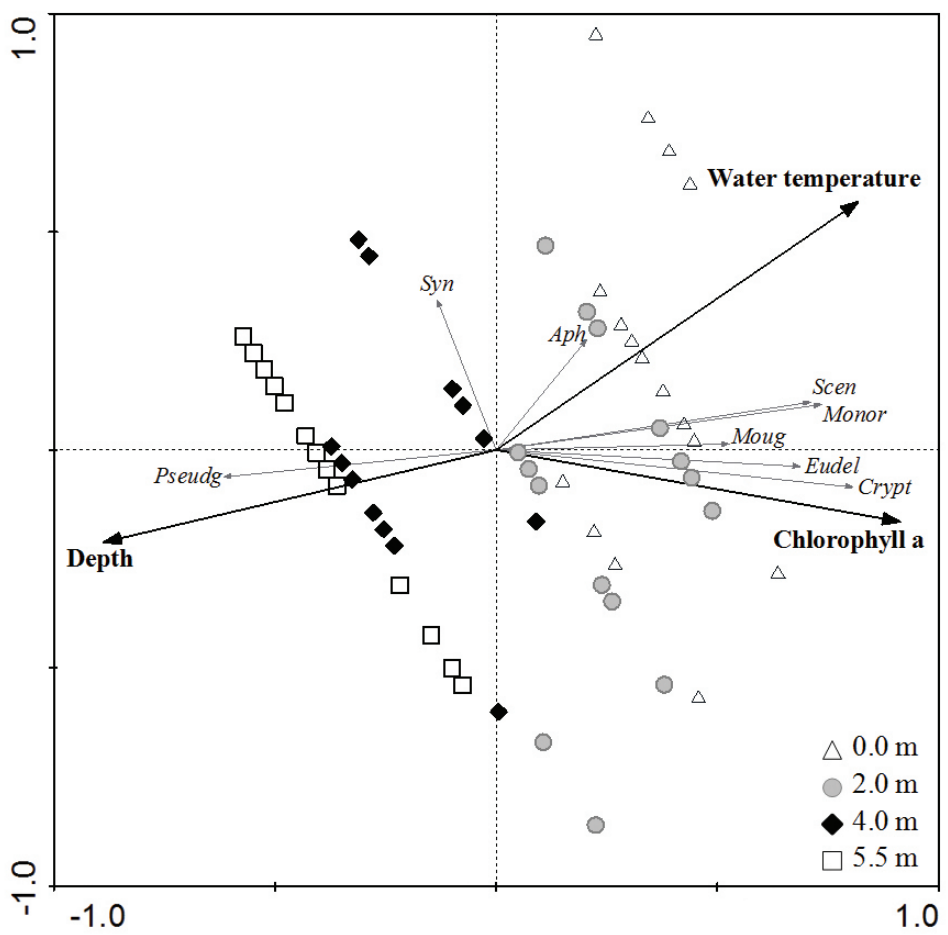

Figure 6. Redundancy analysis (RDA) ordination diagram relating the vertical distribution of dominant phytoplankton species to environmental variables (depth, water temperature and chlorophyll $a$ ) and to the water column layers. (Aph = Aphanocapsa delicatissima; Crypt = Cryptomonas sp.; Eudel = Eudorina elegans; Monor = Monoraphidium contortum; Moug = Mougeotia sp.; Pseudg = Pseudanabaena galeata ; Scen = Scenedesmus ecornis and Syn = Synechococcus sp.). 
followed by partial mixing of the water column. Day-time heating created new temperature gradients in the upper layer resulting in a multi-stepped stable metalimnion. During the night, as surface water cooled, the density increased making this layer heavier than the one beneath it and causing convectional mixing and thermocline deepening.

In the early hours of the day, the surface layer became well mixed, mainly by the penetrative convection associated with the loss of heat from the surface layer during the night. A thermocline could be clearly distinguished at the base of this well-mixed layer. As the air temperature rose during the morning, so did that of the water surface layer. The thermocline remained shallow, at a depth of $2.0 \mathrm{~m}$ or less, owing to heat diffusion within the epilimnion. The wind blew throughout the day, causing turbulent kinetic energy in the surface layer, reinforcing the downward transport of heat, lowering the water temperature near the surface and deepening the thermocline. New thermoclines started forming in the deeper water, within a stepped metalimnion of thermoclines accumulated during net heating of the surface layer, a process commonly seen in tropical lakes (Lewis, 1973; Barbosa and Padisak, 2002).

The wind blowing during the day was strong on the first day, generating moderate stratification and a more even distribution of phytoplankton in the water column. During the night, with a stable and deeper thermocline, the highest concentrations of phytoplankton were found in the upper layers.

In Payne's view (1986), the metalimnion may act as a second bottom for the water column, where the sedimentation of particles may be prevented by its marked density gradient. The metalimnion in the Guarapiranga Reservoir water column indeed acted as a second bottom keeping the chlorophyceans Scenedesmus ecornis and Eudorina elegans practically isolated from the filamentous cyanobacterium Pseudanabaena galeata, which was only found in the hypolimnion.

The second day was marked by stronger stratification, determined by a greater heat influx and more constant wind speed. Phytoplankton in the upper layers appeared to have favorable conditions for growth during the second diel cycle, since light and temperature were adequate and nutrients were not limiting.

This could be an explanation for the marked increase of Aphanocapsa delicatissima, whose density almost doubled over the first 12 hours. According to the literature, a species of this genus, A. elachista, has a doubling time of approximately 15 hours (Rippka, 1972).

It may be hypothesized that at least part of the increase in A. delicatissima density and that of some co-dominant algae could be due to population growth, implying a biological response of phytoplankton replication in a shorter time than the range of 50-200 hours suggested by Harris (1986).

The high availability of nutrients in Guarapiranga Reservoir was noted in previous work (Gemelgo et al., 2009) in which the inorganic nitrogen compounds and total phosphorus were recorded, and also from the total nutrients measured in the present study. During that study the temperature and euphotic zone were around $20^{\circ} \mathrm{C}$ and $3 \mathrm{~m}$, respectively.

Most species remained in the upper 0.0 and $2.0 \mathrm{~m}$ depth. In some cases, this can be related to the small cells size (Scenedesmus ecornis and Synechococcus sp.) or to the buoyancy of the colony mucilaginous matrix (Aphanocapsa delicatissima) that avoid sedimentation (Barbosa et al., 2011). Even large filamentous species such as Mougeotia sp. were held in the upper layer for long periods. This alga was possibly detached from floating macrophyte periphyton by the water movements in the upper layer. During the morning and early afternoon of the second diel cycle, air temperature increased by $5.6^{\circ} \mathrm{C}$ and net heat flux was high, with a $1.4^{\circ} \mathrm{C}$ rise in the upper layer. Mougeotia sp. filaments were kept in the well mixed epilimnion by the strong density gradient. This could also be the case of the large flagellated Eudorina elegans and Cryptomonas sp. that remained mainly at the surface. Although these species are able to swim against gravity, according to Reynolds et al. (1983) the fastest velocities they can attain (usually less than $1 \mathrm{~mm} \mathrm{~s}^{-1}$ ) are slower than the turbulent velocities generated by a wind of $1 \mathrm{~m} \mathrm{~s}^{-1}$. In both diel cycles there were light winds of 3-4 $\mathrm{m} \mathrm{s}^{-1}$, which can develop turbulence that far exceeds the speed of most motile algal species.

Pseudanabaena galeata was the only one of the abundant species that appeared only in the deep layers (4.0 and $5.5 \mathrm{~m}$ ) of Guarapiranga Reservoir. Other studies (e.g. Barbosa et al., 2011) also found this species in the deepest layer of a tropical stratified lake (Lake Carioca, $\mathrm{MG}$, Brazil). It is known that this species preferentially occupies the deeper layers, owing to its tolerance to light deficiency (Reynolds et al., 2002).

In conclusion, air temperature and wind speed were the most important meteorological factors altering the thermal structure of Guarapiranga Reservoir during the two-day period, promoting short-term diurnal patterns of stratification and night-time mixing.

The vertical distribution of the main phytoplankton species was related to the thermal stratification and hydrodynamic events. During periods of moderate stratification and low winds, both small and large cells, colonies or filaments were more evenly distributed in the water column, whereas during periods of thermal stratification all species, except Pseudanabaena galeata, were trapped in the upper layers by the strong density gradient and extended metalimnion.

Our findings show that in tropical polymictic reservoirs the hydrodynamic events associated with thermal stratification and water-layer mixing do determine most patterns of vertical distribution of algal populations. Wind speed and direction are important variables that must be included for a better understanding of the factors controlling phytoplankton vertical distribution and consequently their physiological functional performance. 


\section{Acknowledgements}

The authors thank SABESP for the financial support for this research and CAPES for the scholarship for the first author.

\section{References}

BARBOSA, FAR. and PADISÁK, J., 2002. The forgotten lake stratification pattern: atelomixia, and its ecological importance. Verhandlungen des Internationalen Verein Limnologie, vol. 28, p. 1385-1395.

BARBOSA, LG., MAIA-BARBOSA, PM. and BARBOSA, FARB., 2011. Vertical distribution of phytoplankton functional groups in a tropical shallow lake: driving forces on a diel scale. Acta Limnologica Brasiliensia, vol. 23, no. 1, p. 63-73. http:// dx.doi.org/10.4322/actalb.2011.020.

BECKER, V., CARDOSO, LS. and HUSZAR, VLM., 2009. Diel variation of phytoplankton functional groups in a subtropical reservoir in southern Brazil during an autumnal stratification period. Aquatic Ecology, vol. 43, no. 2, p. 285-293. http://dx.doi. org/10.1007/s10452-008-9164-0.

BEYRUTH, Z., 2000. Periodic disturbances, trophic gradient and phytoplankton characteristics related to cyanobacterial growth in Guarapiranga Reservoir, São Paulo State, Brazil. Hydrobiologia, vol. 424, no. 1-3, p. 51-65. http://dx.doi.org/10.1023/A:1003944726346.

CANTIN, A., BEISNER, BE., GUNN, JM., PRAIRIE, YT. and WINTER, JG., 2011. Effects of thermocline deepening on lake plankton communities. Canadian Journal of Fisheries and Aquatic Sciences, vol. 68, no. 2, p. 260-276. http://dx.doi. org/10.1139/F10-138.

CARLSON, RE., 1977. Trophic state index for lakes. Limnology and Oceanography, vol. 22, no. 2, p. 361-369. http://dx.doi. org/10.4319/lo.1977.22.2.0361

COLINA, M. and GARDINER, PHE., 1999. Simultaneous determination of total nitrogen, phosphorus and sulphur by means of microwave digestion and ion chromatography. Journal of Chromatography A, vol. 847, no. 1-2, p. 285-290. http://dx.doi. org/10.1016/S0021-9673(99)00024-2.

GEMELGO, MCP., MUCCI, JLN. and NAVAS-PEREIRA, D., 2009. Population dynamics: seasonal variation of phytoplankton functional groups in Brazilian reservoirs (Billings and Guarapiranga, São Paulo). Revista Brasileira de Biologia = Brazilian Journal of Biology, vol. 69, no. 4, p. 1001-1013. http://dx.doi.org/10.1590/ S1519-69842009000500004. PMid:19967171

HAMMER, O., HARPER, DAT. and RIAN, PD., 2001. Past: Palaeonthological statistics software package for education and data analysis. Version. 1.37.

HARRIS, GP., 1986. Phytoplankton ecology: Structure, function and fluctuation. London: Chapman and Hall.. http://dx.doi. org/10.1007/978-94-009-4081-9.

HUTCHINSON, GE., 1957. A treatise on limnology. New York: John Wiley.

IMBERGER, J. and PATTERSON, JC., 1989. Physical limnology. In HUTCHINSON, JW. and WU, T. Advances in applied mechanics. Boston: Academic Press. p. 303-475.

LEWIS, WM., 1973. The thermal regime of Lake Lanao (Philippines) and its theoretical implications for tropical lakes.
Limnology and Oceanography, vol. 18, no. 2, p. 200-217. http:// dx.doi.org/10.4319/1o.1973.18.2.0200.

LEWIS, WMJ., 1987. Tropical limnology. Annual Review of Ecology and Systematics, vol. 18, no. 1, p. 159-184. http://dx.doi. org/10.1146/annurev.es.18.110187.001111.

LOPES, MRM., BICUDO, CEM. and FERRAGUT, MC., 2005. Short term spatial and temporal variation of phytoplankton in a shallow tropical oligotrophic reservoir, southeast Brazil. Hydrobiologia, vol. 542, no. 1, p. 235-247. http://dx.doi.org/10.1007/ s10750-004-8332-z.

MACINTYRE, S., ROMERO, JR. and KLING, GW., 2002. Spatial-temporal variability in surface layer deepening and lateral advection in an embayment of Lake Victoria, East Africa. Limnology and Oceanography, vol. 47, no. 3, p. 656-671. http:// dx.doi.org/10.4319/lo.2002.47.3.0656.

MARGALEF, R., 1983. Limnologia. Barcelona: Omega.

NUSH, EA., 1980. Comparison of different methods for chlorophyll and phaeopigments determination. Archiv fuer Hydrobiologie, vol. 14, p. 14-36.

PAYNE, AL., 1986. The ecology of tropical lakes and rivers. New York: John Wiley and Sons.

REYNOLDS, CS., 1984. The ecology of freshwater phytoplankton. Cambridge: Cambridge University Press.

REYNOLDS, CS., WISEMAN, SW., GODFREY, BM. and BUTTERWICK, C., 1983. Some effects of artificial mixing on the dynamics of phytoplankton populations in large limnetic enclosures. Journal of Plankton Research, vol. 5, no. 2, p. 203234. http://dx.doi.org/10.1093/plankt/5.2.203.

REYNOLDS, CS., HUZSAR, V., KRUK, C., FLORES-NASELLI, L. and MELO, S., 2002. Towards a functional classification of the freshwater phytoplankton. Journal of Plankton Research, vol. 24, no. 5, p. 417-428. http://dx.doi.org/10.1093/plankt/24.5.417.

ROS, J., 1979. Praticas de ecologia. Barcelona: Omega.

RIPPKA, R., 1972. Photoheterotrophy and chemoheterotrophy among unicellular blue-green algae. Archives of Microbiology, vol. 87, no. 1, p. 93-98.

SARMENTO, H., 2012. New paradigms in tropical limnology: the importance of the microbial food web. Hydrobiologia, vol. 686, no. 1, p. 1-14. http://dx.doi.org/10.1007/s10750-012-1011-6.

TALLING, JF., 1966. The annual cycle of stratification and phytoplankton growth in Lake Victoria (East Africa). Internationale Revue der Gesamten Hydrobiologie, vol. 51, no. 4, p. 545-621. http://dx.doi.org/10.1002/iroh.19660510402.

TER BRAAK, CJF. and ŠMILAUER, P., 2002. Canoco reference manual and CanoDraw for Windows user's guide: software for canonical community ordination. New York: Microcomputer Power.

TOLEDO, AP., TALARICO, M., CHINEZ, SJ. and AGUDO, EG., 1983. A aplicação de modelos simplificados para avaliação do processo da eutrofização em lagos e reservatórios tropicais. In Anais do XII Congresso Brasileiro de Engenharia Sanitária e Ambiental, 1983. Camboriú. Camboruí: Associação Brasileira de Engenharia Sanitária. p. 1-34.

UTERMÖHL, H., 1958. Zur Vervollkommung der quantitativen phytoplankton methodik. Mitteilungen der Internationalen Vereinigung für Limnologie, vol. 9, p. 1-38. 